\title{
Evidence for local outbreeding depression in the Mediterranean island endemic Anchusa crispa Viv. (Boraginaceae)
}

\author{
ANGÉLIQUE QUILICHINI††, MAX DEBUSSCHE† \& JOHN D. THOMPSON*† \\ $\dagger$ Centre d'Ecologie Fonctionnelle et Evolutive, C.N.R.S., 1919, Route de Mende, 34293 Montpellier cedex 5, France \\ and $¥$ Biologie et Ecologie Végétales, Université de Corse, B.P. 52, 20250 Corte, France
}

\begin{abstract}
In this study we examined the relative effects of inbreeding and outbreeding on offspring fitness over two generations in Anchusa crispa Viv., a rare species which on Corsica (France) occurs in small populations composed of patches of few individuals. Self- and outcross-pollinations were carried out in a single population and $F_{1}$ progeny grown to flowering. Plants grown from selfing and outcrossing were then selfed or outcrossed to produce $F_{2}$ individuals in four combinations of pollination treatments over two generations, i.e. self + self, self + outcross, outcross + self and outcross + outcross. In the $\mathrm{F}_{1}$ generation, selfed progeny had a significantly greater number of cymes per plant than outcrossed progeny $(P=0.006)$. Plants from two generations of selfing had fewer seeds per fruit $(P=0.06)$ but a significantly greater survival rate $(P<0.001)$ and a greater number of cymes $(P=0.06)$ than those from two generations of outcrossing. Selfed $\mathrm{F}_{2}$ from outcrossed $\mathrm{F}_{1}$ had a significantly greater number of cymes $(P<0.01)$ than outcrossed $F_{2}$ from outcrossed $F_{1}$. In the comparison between selfed and outcrossed $\mathrm{F}_{2}$ from selfed $\mathrm{F}_{1}$ the former had a significantly greater survival rate $(P<0.001)$, but the latter significantly more flowers per cyme $(P<0.05)$. Together, these results indicate that outbreeding depression may occur on a very local scale within populations of this rare endemic species, with important implications for the conservation of rare plants.
\end{abstract}

Keywords: Boraginaceae, conservation, endemism, inbreeding depression, island, mating system, outbreeding depression.

\section{Introduction}

In many plant species, inbreeding is associated with reduced performance of selfed progeny relative to those produced by outcrossing (see Husband \& Schemske, 1996 for a review). The magnitude of inbreeding depression can vary within and among closely related species in relation to the inbreeding history of the population studied (Husband \& Schemske, 1996; Affre \& Thompson, 1999) and the environmental conditions in which inbreeding depression is studied (Charlesworth \& Charlesworth, 1987; Dudash, 1990; Carr \& Dudash, 1995). Inbreeding depression may be low or absent in populations or species with a history of inbreeding if reduced performance is due to homozygosity for deleterious recessive alleles (reviewed by Husband \& Schemske, 1996; Byers \& Waller, 2000).

Comparison of the effects of inbreeding vs. outbreeding requires that the genetic relatedness of outcrossed

*Correspondence. E-mail: john.thompson@cefe.cnrs-mop.fr individuals be considered, since, beyond a certain degree of relatedness outcrossing may itself be associated with a decline in fitness, either due to local adaptation to environmental conditions or the coadaptation of different genes. Of particular interest is the spatial scale at which problems arise when genetically different lineages are crossed. Reduced fitness after crossing is often observed as hybrid inviability in crosses among related species or subspecies (reviewed in Templeton, 1986; Waser, 1993) and as outbreeding depression in crosses among geographically isolated populations of a single species (Templeton, 1986; Waser \& Price, 1994; Trame et al., 1995; Fischer \& Matthies, 1997; Affre \& Thompson, 1999). Such outbreeding depression may also occur on a highly localized scale within or between adjacent plant populations. In Delphinium nelsonii, an optimal outcrossing distance exists below and above which seed set per flower is reduced (Price \& Waser, 1979; Waser \& Price, 1991). In the highly inbred annual legume, Amphicarpaea bracteata, hybridization between closely related and spatially adjacent biotypes is restricted due 
to negative effects of crossing on progeny fitness (Parker, 1992).

The number of studies demonstrating that outbreeding may have negative effects on plant fitness on a local scale nevertheless remains too few for a proper evaluation of the significance of outbreeding depression on a localized scale (Schierup \& Christiansen, 1996). Anchusa crispa Viv. (Boraginaceae) is a short-lived perennial herb, endemic to sandy seashores on the Mediterranean islands of Corsica (France) and Sardinia (Italy) where it occurs in a relatively homogeneous environment (in open herbaceous vegetation on low-lying dunes). On Corsica, populations are small $(<400$ individuals) and consist of distinct patches of 10-15 plants (Quilichini, 1999). Anchusa crispa has small blue tubular flowers (7-10 $\mathrm{mm}$ in diameter) with the stigma adjacent to the anthers, and lacks any spatial or temporal floral mechanism to facilitate outcrossing. Isozyme analysis indicates that populations are completely homozygous and fixed for single (sometimes different) alleles at several loci (Quilichini, 1999). This species thus appears to be highly inbred, although founder effects may also have been the initial cause of such gene fixation.

The purpose of this paper is to quantify the relative performance of progeny derived from selfing and outcrossing within populations over two generations of the life cycle of $A$. crispa grown in glasshouse conditions. We ask the following questions. (1) Is this species selffertile and capable of setting seeds in the absence of pollinators (a characteristic which would increase inbreeding and local differentiation)? (2) Is there any evidence for inbreeding depression in this species? (3) Alternatively, does this species show evidence for a decline in performance after outcrossing between patches in a single population?

\section{Materials and methods}

\section{Study species}

Populations of Anchusa crispa occur in three geographically separate areas: two bays on Corsica, one on the west coast (Salis-Marschlins, 1834; Paradis \& Piazza, 1988; Thiébaud, 1988; Paradis \& Piazza, 1989) and one on the east coast (Salis-Marschlins, 1834; Conrad et al., 1989); and a third on the north-west coast of Sardinia (Valsecchi, 1976; Selvi \& Bigazzi, 1998). It occurs at seven sites on Corsica and 10 sites on Sardinia. Each site contains from fewer than 10 to a few hundred individuals, with individuals distributed in small patches containing 10-15 plants. Patches are spaced $1 \mathrm{~m}$ to several metres apart. Populations are frequently disturbed by human activities. This species is considered endangered and is protected by French law. Flowering occurs from March to July. In natural conditions, the number of fruits per cyme is generally from 10 to 200 , depending on cyme length (Quilichini, 1999).

\section{Experimental procedure}

Controlled pollinations were carried out on 20 flowering individuals during the 1997 flowering season (the full experimental procedure is outlined in Fig. 1) in the Capu Laurosu population on the west coast of Corsica. On each individual, 40 flower buds were randomly selected and 10 flowers allocated to each of four treatments:

1 Control: 10 flowers were left for open-pollination.

2 Spontaneous self-pollination: 10 flowers were enclosed in a paper bag while the flowers were still in bud and left untouched.

3 Experimental self-pollination (selfed): 10 flowers in bud were enclosed as in treatment (2). As flowers

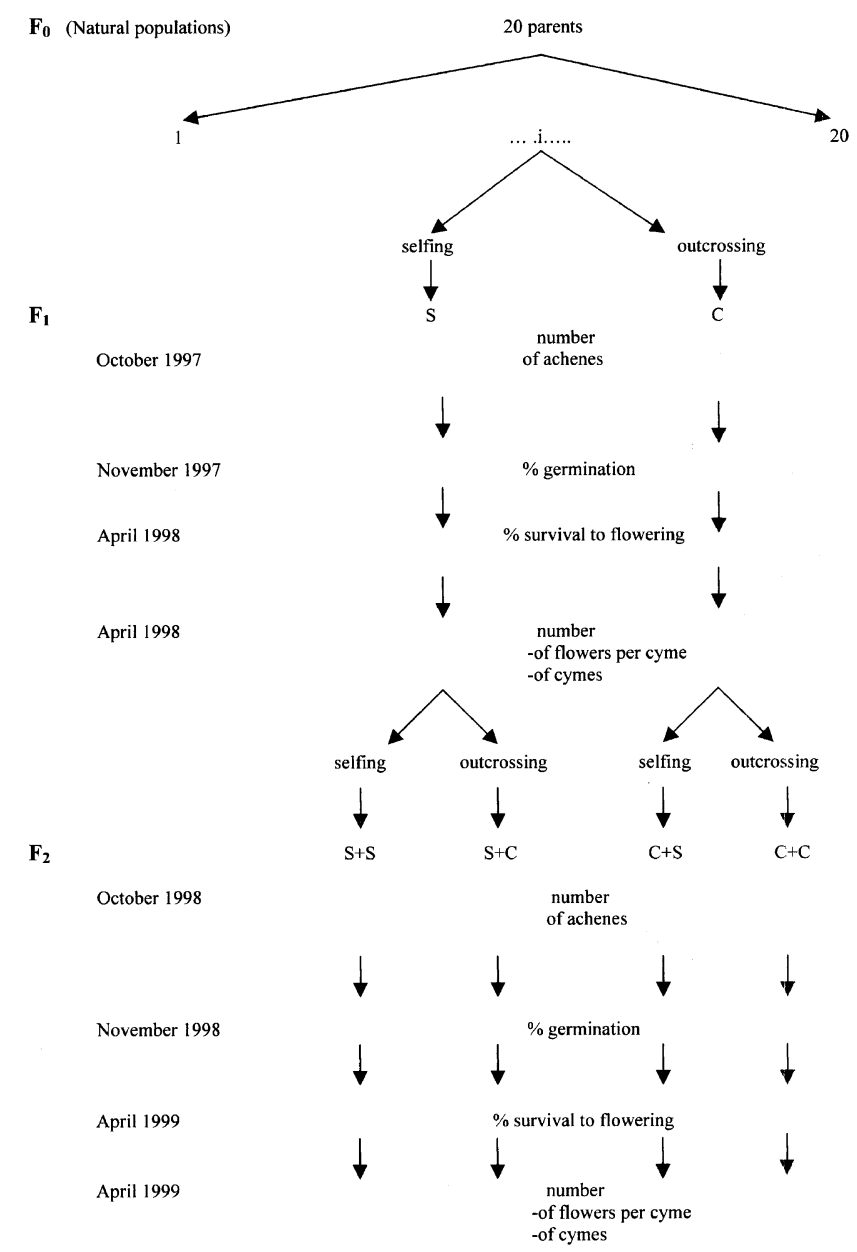

Fig. 1 Diagrammatic presentation of the pollination experiment used to produce selfed (S) and outcrossed (C) $F_{1}$ and $F_{2}$ Anchusa crispa. 
opened, they were emasculated by removal of the corolla and hand-pollinated using self-pollen from the same flower. Pollen was applied with a separate tooth-pick for each flower.

4 Cross-pollination (outcrossed): 10 flowers were enclosed as above. As flowers opened, they were emasculated as above and then pollinated with pollen from a plant in a different patch, 5-10 $\mathrm{m}$ away from the target plant. Four crosses were carried out with a pollen donor 5-10 $\mathrm{m}$ away, six with a pollen donor 10-20 m away, the remainder with a donor $20-30 \mathrm{~m}$ away.

For each treatment, the 10 flowers were on a single cyme, and marked with coloured fingernail polish. Achenes from each flower were collected as they matured. Fruit per flower and achene number per fruit were then determined.

In October 1997, 30 achenes produced from treatments 3 and 4 on each maternal plant were germinated in $100 \times 15 \mathrm{~mm}$ Petri dishes, containing three $9 \mathrm{~cm}$ filter paper disks placed on cotton-wool moistened with distilled water. The dishes were placed in a single randomised block in a glasshouse in the CEFE-CNRS experimental gardens (Montpellier, France). Seeds were germinated at $18-20^{\circ} \mathrm{C}$, under day-night conditions, and distilled water was added as needed. Percentage germination was measured in November 1997, after which no further germination occurred. Plants were transplanted to plastic pots with a 2:1 garden soil: sand mix and grown to flowering in a glasshouse throughout winter and spring 1997-98 in a single randomised block. During the 1998 flowering season, the number of cymes and the number of flowers per cyme (all flowers on three cymes) were quantified on all individuals.

Pollination of $F_{1}$ individuals was conducted in April 1998 in glasshouse conditions. One $F_{1}$ plant from each family of selfed and outcrossed individuals from the 20 original $F_{0}$ plants (Fig. 1) was randomly selected and placed in a single randomised block. Two types of pollination were carried out on each plant: (1) selfpollination; or (2) outcross-pollination with a pollen donor from the outcrossed offspring of a different $F_{0}$ maternal parent. Each treatment was performed on 10 flowers of a single cyme. In this way, we achieved a gradient of cumulative inbreeding: two generations of successive selfing $(S+S)$, one generation of selfing followed by one generation of outcrossing $(\mathrm{S}+\mathrm{C})$ and vice versa $(\mathrm{C}+\mathrm{S})$, and two generations of outcrossing $(\mathrm{C}+\mathrm{C})$.

\section{Data analysis}

Relative performances after selfing and outcrossing were estimated for: (1) the number of achenes per fruit;
(2) percentage germination; (3) percentage survival; (4) the number of cymes per plant; and (5) the number of flowers per cyme, using the formula $\left(W_{\mathrm{o}}-W_{\mathrm{s}}\right) /$ $W_{\text {maximum }}$. $W_{\mathrm{o}}$ is the performance of outcrossed progeny, $W_{\mathrm{s}}$ is the performance of selfed progeny and $W_{\text {maximum }}=W_{\mathrm{o}}$ when the performance on outcrossing is greater than or equal to that on selfing and $W_{\text {maximum }}=$ $W_{\mathrm{s}}$ when the performance on selfing is greater than on outcrossing (e.g. Agren \& Schemske, 1993; Affre \& Thompson, 1999). This estimate varies from -1 to +1 .

For the $\mathrm{F}_{2}$ generation, three levels of relative performance were analysed, depending on the $F_{1}$ treatment from which individuals were derived. First, the performance of selfed (S) and outcrossed (C) $\mathrm{F}_{2}$ produced from the selfed $F_{1}$ plants $(S+S$ compared with $S+C)$ was compared. Second, the performance of selfed and outcrossed $\mathrm{F}_{2}$ progeny derived from the offspring of outcrossed $\mathrm{F}_{1}(\mathrm{~S}+\mathrm{C}$ compared with $\mathrm{C}+\mathrm{C})$ was compared. Third, the performance after two generations of self-pollination was compared with that after two generations of outcross-pollination $(\mathrm{S}+\mathrm{S}$ compared with $\mathrm{C}+\mathrm{C}$ ). Variation in performance after selfing and outcrossing at the different life cycle stages was analysed by ANOVA using the GLM procedure of SAS (SAS, 1990). Percentage germination and survival for each progeny were analysed using a binomial error in GLIM (Crawley, 1993). Several $F_{2}$ families produced no offspring on either selfing or outcrossing. The offspring for comparisons in the $F_{2}$ families involved paired selfed and outcrossed progeny in the same maternal lineages in order to avoid any maternal effects. Unfortunately by restricting our comparisons in this way we were forced to reduce sample sizes in the analyses of the $F_{2}$. We thus interpret our results in the light of small sample sizes for the $\mathrm{F}_{2}$ generation.

\section{Results}

There was no significant difference between pollination treatments on $\mathrm{F}_{0}$ maternal plants in the field for either mean fruit number per plant (d.f. $=3, F=0.23$, $P=0.87$ ), which ranged from 85 to $90 \%$ for the four treatments or the mean number of achenes per fruit (d.f. $=3, F=0.53, P=0.66$ ), which ranged from 3.2 to 3.6. Anchusa crispa is thus both highly self-fertile (capable of autonomous self-pollination) and self-compatible. The presence of the paper bag also had no effect on fertilization, since open-pollinated plants and all three treatments on bagged plants had similarly high levels of fruit set.

The only significant difference between selfed and outcrossed progeny in the $F_{1}$ generation occurred late in the life cycle, where we observed a significantly greater number of cymes on plants produced by selfing than on 
Table 1 Mean performance values $( \pm \mathrm{SE})$ and values of inbreeding depression $(\delta)$ for each life cycle stage in the $\mathrm{F}_{1}$ generation of Anchusa crispa. Sample sizes (number of families) used to calculate mean values are given in parentheses

\begin{tabular}{llllll}
\hline & $\begin{array}{c}\text { No. of achenes } \\
\text { per fruit }\end{array}$ & \multicolumn{1}{c}{$\begin{array}{c}\text { Percent } \\
\text { germination }\end{array}$} & \multicolumn{1}{c}{$\begin{array}{c}\text { Percent } \\
\text { survival }\end{array}$} & $\begin{array}{c}\text { No. of cymes } \\
\text { per plant }\end{array}$ & \multicolumn{1}{c}{$\begin{array}{c}\text { No. of flowers } \\
\text { per cyme }\end{array}$} \\
\hline Self-pollination & $3.3 \pm 0.22(20)$ & $90.5 \pm 3.5(20)$ & $97.6 \pm 1.3(18)$ & $5.3 \pm 0.2(18)$ & $12.6 \pm 0.7(18)$ \\
Cross-pollination & $3.5 \pm 0.1(20)$ & $83 \pm 5.7(20)$ & $100(18)$ & $4.4 \pm 0.2(18)$ & $13 \pm 0.8(18)$ \\
$F$ & 0.41 & $\left(\chi^{2}\right) 2.41$ & $\left(\chi^{2}\right) 2.89$ & 8.86 & 0.17 \\
d.f. & 1 & 1 & 1 & 1 & 1 \\
$P$ & 0.52 & 0.151 & 0.101 & $0.006^{* *}$ & 0.687 \\
$\delta$ & 0.05 & -0.08 & 0.024 & -0.17 & 0.03 \\
\hline
\end{tabular}

$* * P<0.01$

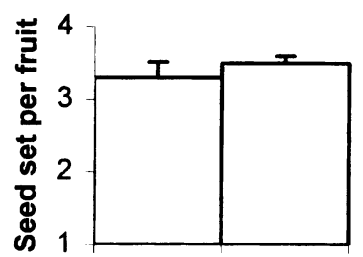

S C
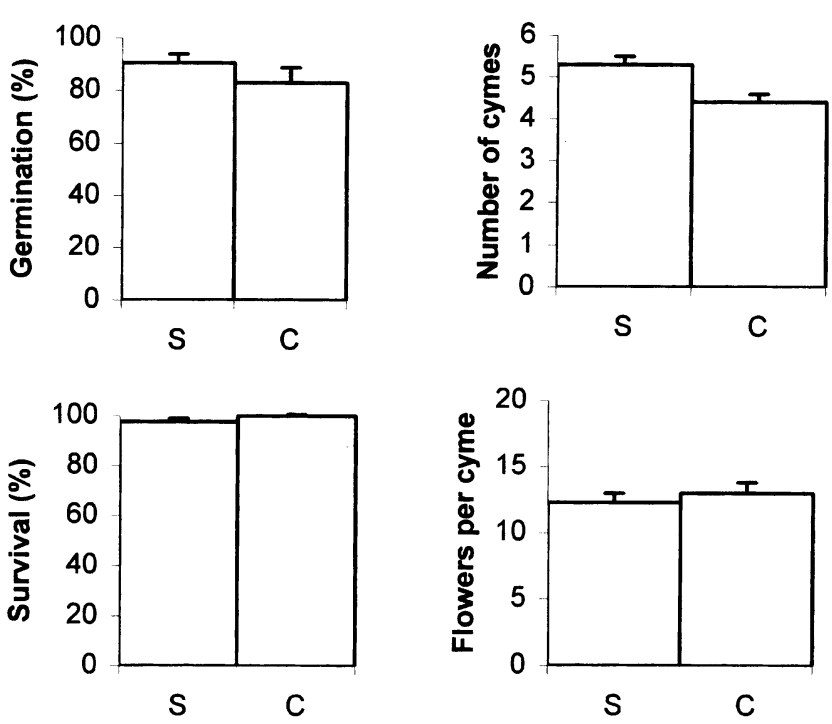

Fig. 2 Mean ( \pm SE) values per family of relative performance across the $\mathrm{F}_{1}$ generation of Anchusa crispa grown under glasshouse conditions, after selfing (S) and outcrossing (C).

plants produced by outcrossing (Table 1; Fig. 2). Outbreeding depression $(\delta=-0.17)$ was thus observed at this stage. Following selfing in the $F_{1}$, significant outbreeding depression was observed for percentage survival and significant inbreeding depression was observed for the number of flowers per cyme (Table 2; Fig. 3). Following outcrossing in the $F_{1}$, we observed significant inbreeding depression on seed number per fruit, but significant outbreeding depression in the production of cymes and the number of flowers per cyme (Table 2; Fig. 3). The comparison of selfed $F_{2}$ from a selfed $F_{1}$ with outcrossed $F_{2}$ from an outcrossed $F_{1}$ showed significant outbreeding depression in percentage survival and number of cymes (Table 2; Fig. 3).

\section{Discussion}

The lack of inbreeding depression in the $F_{1}$ generation, and the outbreeding depression expressed in both the $F_{1}$ and $\mathrm{F}_{2}$ generations suggests that Anchusa crispa has not only purged deleterious alleles, but also may have undergone some form of selection for inbreeding either due to coadaptation between loci or local adaptation.

Waser (1993) reviewed 25 studies in which the effects of selfing and outcrossing on seed production had been quantified and found evidence for outbreeding depression in more than $70 \%$ of these, at different spatial scales, mainly on seed-set in the $F_{1}$. Evidence of outbreeding depression has frequently been reported for progeny from crosses between related species or in a single species at different scales (Sobrevilla, 1988; Waser \& Price, 1989, 1994; Waser, 1993). Some studies have shown that outbreeding depression may occur in crosses between geographically separated populations of a single species (Levin, 1983; Sobrevilla, 1988; Fischer \& Matthies, 1997; Affre \& Thompson, 1999). On a finer scale, crosses between hybrids of Amphicarpaea bracteata, growing in the same population and sometimes at distances of less than $20 \mathrm{~cm}$, resulted in progeny with reduced fitness (Parker, 1992). In fact, for a single species, the relative performance on selfing and outcrossing may vary with the distance between parents in a way that suggests the existence of an optimal outcrossing distance (Price \& Waser, 1979; Waser \& Price, 1989, 1994). Our results provide further evidence for the occurrence of negative outbreeding effects on a highly localized scale between patches of individuals several metres apart in a population of A. crispa.

Outbreeding depression may stem from two principal causes, local adaptation to environmental variation or the coadaptation of genes at different loci (Ritland \& Ganders, 1987; Lynch, 1991; Waser, 1993). First, the

(C) The Genetics Society of Great Britain, Heredity, 87, 190-197. 
Table 2 Comparison of mean ( \pm SE) performance on selfing and outcrossing for each life stage in the $F_{2}$ generation of Anchusa crispa, for (a) two generations of either selfing or outcrossing (b) after selfing in the $\mathrm{F}_{1}$ and (c) after outcrossing in the $\mathrm{F}_{1}$. The value of inbreeding depression $(\delta)$ is given for each stage, and the sample size (No. of families) are given in parentheses

(a) Two generations of selfing or outcrossing

\begin{tabular}{llllll}
\hline & $\begin{array}{c}\text { No. of achenes } \\
\text { per fruit }\end{array}$ & \multicolumn{1}{c}{$\begin{array}{c}\text { Percent } \\
\text { germination }\end{array}$} & $\begin{array}{c}\text { Percent } \\
\text { survival }\end{array}$ & $\begin{array}{c}\text { No. of cymes } \\
\text { per plant }\end{array}$ & $\begin{array}{c}\text { No. of flowers } \\
\text { per cyme }\end{array}$ \\
\hline Self-pollination & $0.84 \pm 0.1(8)$ & $50 \pm 8(8)$ & $100(8)$ & $2.1 \pm 0.5(8)$ & $6.2 \pm 1.9(8)$ \\
Cross-pollination & $1.23 \pm 0.1(8)$ & $60 \pm 18(8)$ & $79.2 \pm 8.5(8)$ & $0.8 \pm 0.3(8)$ & $5.5 \pm 1.9(8)$ \\
$F$ & 3.8 & $\left(\chi^{2}\right) 0.81$ & $\left(\chi^{2}\right) 11.9$ & 4.02 & 0.05 \\
d.f. & 1 & 1 & 1 & 1 & 0.06 \\
$P$ & 0.06 & 0.37 & $0.0005^{* *}$ & -0.62 & 0.82 \\
$\delta$ & 0.31 & 0.16 & -0.20 & -0.11 \\
\hline
\end{tabular}

(b) Selfed $F_{1}$

\begin{tabular}{llllll}
\hline & $\begin{array}{c}\text { No. of achenes } \\
\text { per fruit }\end{array}$ & $\begin{array}{c}\text { Percent } \\
\text { germination }\end{array}$ & $\begin{array}{c}\text { Percent } \\
\text { survival }\end{array}$ & $\begin{array}{c}\text { No. of cymes } \\
\text { per plant }\end{array}$ & $\begin{array}{c}\text { No. of flowers } \\
\text { per cyme }\end{array}$ \\
\hline Self-pollination & $0.84 \pm 0.1(8)$ & $50 \pm 8(8)$ & $100(8)$ & $2.1 \pm 0.5(8)$ & $6.2 \pm 1.3(8)$ \\
Cross-pollination & $0.9 \pm 0.1(8)$ & $55 \pm 10(8)$ & $72.7 \pm 9.7(8)$ & $2 \pm 0.3(8)$ & $12.3 \pm 1.4(8)$ \\
$F$ & 0.14 & $\left(\chi^{2}\right) 0.26$ & $\left(\chi^{2}\right) 16.4$ & 0 & 6.92 \\
d.f. & 1 & 1 & 1 & 1 & 0.95 \\
$P$ & 0.71 & 0.61 & $0.00004 * * *$ & -0.04 & $0.02 *$ \\
$\delta$ & 0.06 & 0.09 & -0.27 & & 0.49 \\
\hline
\end{tabular}

(c) Outcrossed $F_{1}$

\begin{tabular}{|c|c|c|c|c|c|}
\hline & $\begin{array}{c}\text { No. of achenes } \\
\text { per fruit }\end{array}$ & $\begin{array}{c}\text { Percent } \\
\text { germination }\end{array}$ & $\begin{array}{l}\text { Percent } \\
\text { survival }\end{array}$ & $\begin{array}{l}\text { No. of cymes } \\
\text { per plant }\end{array}$ & $\begin{array}{c}\text { No. of flowers } \\
\text { per cyme }\end{array}$ \\
\hline Self-pollination & $0.82 \pm 0.1(8)$ & $65 \pm 7.6(8)$ & $88.4 \pm 17.4(8)$ & $2.3 \pm 0.3(8)$ & $9.5 \pm 1.9(8)$ \\
\hline$F$ & 3.11 & $\left(\chi^{2}\right) 0.21$ & $\left(\chi^{2}\right) 0.81$ & 9.64 & 2.02 \\
\hline d.f. & 1 & 1 & 1 & 1 & 1 \\
\hline
\end{tabular}

$* P<0.05 ; * * P<0.01 ; * * * P<0.001$.

evolution of adaptation to local conditions may cause outcrossing among individuals adapted to different parental environments to produce offspring not adapted to either parental environment. Inbreeding can be favoured if a recessive homozygote is favoured in particular environments, as reported for genes responsible for heavy metal tolerance (Antonovics, 1968). Local adaptation could thus be a cause of outbreeding depression in plants due to spatial heterogeneity in environmental conditions and frequently observed population substructure within plant populations (e.g. Bonnin et al., 1996; Tarayre et al., 1997). It would thus be most worthwhile to study the potential role of adaptation to environmental microsites in A. crispa in order to examine its potential role of the generation of the outbreeding depression we observe.
Second, favourable epistatic interactions among genes at different loci may cause the coadaptation of genes, such that unrelated individuals do not have similar gene combinations. Crosses among individuals with differentially coadapted genomes may break up coadaptation between homologous chromosomes (in the $F_{1}$ ) and between coadapted parts of particular chromosomes (mostly in the $\mathrm{F}_{2}$ after recombination). Genetic drift may allow the development of allelic differences for loci which influence fitness, followed by selection favouring alleles at other loci which show favourable epistatic interactions with fitness loci. The more such loci are affected, the greater the outbreeding depression (Ritland \& Ganders, 1987). Burton (1987, 1990) has shown how parental marker combinations outperform hybrids among local populations in a marine copepod, suggest- 

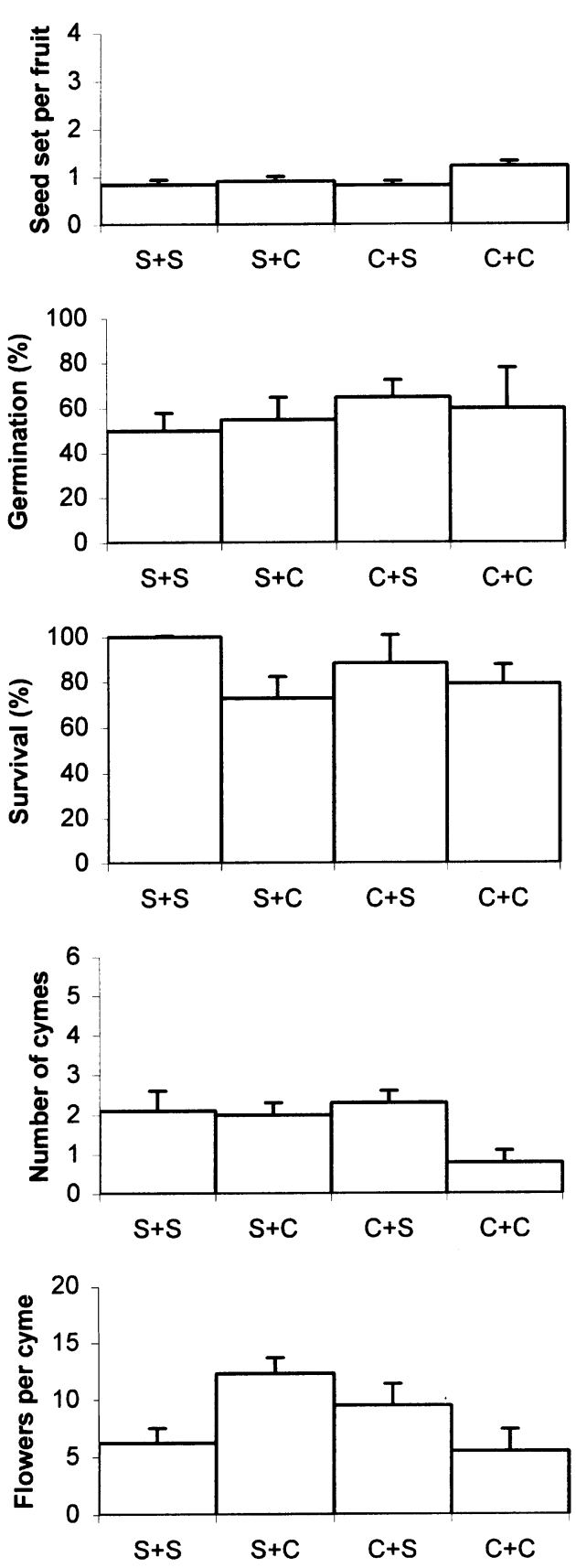

Fig. 3 Mean $( \pm \mathrm{SE})$ values per family of relative performance across the $\mathrm{F}_{2}$ generation of Anchusa crispa grown under glasshouse conditions, after two generations of selfing $(\mathrm{S}+\mathrm{S})$, one generation of selfing and one generation of outcrossing $(\mathrm{S}+\mathrm{C})$, one generation of outcrossing and one generation of selfing $(\mathrm{C}+\mathrm{S})$ and two generations of outcrossing $(\mathrm{C}+\mathrm{C})$.

ing genome integration and potential coadaptation among different genes.

A particularly interesting feature of our results is that in the $F_{2}$ significant outbreeding depression was mostly detected where progeny from outcrossing in the $F_{1}$ were used for comparisons, i.e. after two generations of outcrossing. When selfed and outcrossed $F_{2}$ produced from selfed $F_{1}$ were compared, no outbreeding depression was observed. This result illustrates the importance of studying more than one generation for outbreeding effects to be fully observed (Bertin, 1982; Burton, 1987, 1990; Svensson, 1988). Our $F_{1}$ and $F_{2}$ were grown in subsequent years. Environmental differences could thus have contributed to the greater outbreeding depression expressed by the $\mathrm{F}_{2}$ (see Waser et al., 2000 for a discussion of this issue) and so we do not interpret the difference between the two generations.

Another important result of our study is that outbreeding depression is expressed after seedlings have germinated, during growth and reproduction, but not on viable seed set by maternal parents. The effects detected for cyme and flower production are not affected by differences in fruit set per cyme which was similar in all plants. Seed set data apply not just to the ancestry of the zygotes in the fruits (which may have abortion rates that reflect inbreeding or outbreeding depression) but are also part of the genetic and environmental (via maternal effects) ancestry of the maternal plant. This life-cycle stage thus contains different ancestral components of performance, and effects may be attenuated. Waser \& Price $(1989,1994)$ also found that outcrossing affected seedling emergence and subsequent offspring survival more strongly than seed set on the maternal plants, especially for crosses between parents more than $1 \mathrm{~m}$ apart. These results underline the importance of studying the full life cycle, and also examining $F_{2}$ performance. It would now be most worthwhile to estimate whether the outbreeding depression we observed also occurs in natura for A. crispa.

In $A$. crispa, the existence of outbreeding depression following crosses between individuals in different patches of the same population suggests that the study population is composed of spatially segregated subpopulations each composed of closely related individuals. Several biological characters of A. crispa may have facilitated the development of high levels of inbreeding and highly localized subpopulation differentiation. First, the floral morphology of this A. crispa population is characterized by the close proximity of stigma and anthers (less than $0.1 \mathrm{~mm}$ ), which are enclosed together in the corolla tube. This proximity of stigmas to anthers can permit autonomous selfing in this species. Second, pollinators fly short distances between individuals and as a result, pollen transfer is most likely to occur between flowers of a single plant or plants within patches (Quilichini, personal observation). Third, achenes are dispersed by ants, mostly over relatively short distances (Quilichini \& Debussche, 2000). These three factors will cause pollen 
and seed dispersal to be highly localized within populations, allowing the development of highly inbred groups of related individuals. A combination of small effective population size, limited seed and pollen dispersal, inbreeding and localized environmental heterogeneity may have facilitated the evolution of locally adapted gene complexes in this species (see Levin, 1983). The application of molecular tools to quantify population structure in $A$. crispa would now be most worthwhile.

Furthermore, A. crispa appears to have been rare for a long time. It is known that this species has occurred in small populations, with few individuals, in localized sites for at least 200 years (Viviani, 1825). Maire (1904) considered this species to be rare on Corsica, where plants from several localities described in the 19th century have disappeared. Throughout the 20th century, the search for new sites for $A$. crispa has revealed three new localities on Corsica, all of which are close to those already known (Piazza \& Paradis, 1988; Thiébaud, 1988) and contain few individuals (from eight to less than one hundred). So, at least since its first description in 1825 , the populations of $A$. crispa have been small and patchy.

Knowledge of population differentiation is of critical importance for the conservation of endemic and rare species, particularly in the Mediterranean flora where many endemic species have disjunct and fragmented distributions (Thompson, 1999). When population sizes are drastically reduced and highly disturbed by human activities, one would predict that such populations may be sensitive to extinction due to inbreeding depression (Barrett \& Kohn, 1991; Tanaka, 1997). In contrast, our results show that, in species such as $A$. crispa which may have a long history of small population size and localized mating, reduced performance on outcrossing may occur. The sampling of plants for in situ and ex situ conservation of genetic diversity of $A$. crispa should thus involve seeds from several patches of a given population.

\section{Acknowledgements}

We thank G. Paradis for advice, C. Collin for practical help, and N. Waser and one anonymous reviewer for comments on a previous version of the manuscript. We gratefully acknowledge the financial support provided by the Office de l'Environnement de la Corse and the Collectivité Territoriale de la Corse.

\section{References}

AFFRE, L. AND THOMPSON, J. D. 1999. Variation in self-fertility, inbreeding depression and levels of inbreeding in four cyclamen species. J. Evol. Biol., 12, 113-122.
AGREN, J. AND SCHEMSKE, D. W. 1993. Outcrossing rate and inbreeding depression in two annual monoecious herbs, Begonia hirsuta and B. semiovata. Evolution, 47, 125-135.

ANTONOviCs, J. 1968. Evolution in closely adjacent populations. V. Evolution of self-fertility. Heredity, 23, 319-238.

BARRETT, S.C.H. AND KOHN, J. R. 1991. Genetic and evolutionary consequences of small population size in plants: Implications for Conservation. In: Falk, D. A. and Holsinger, K. E. (eds) Genetics and Conservation of Rare Plants, pp. 3-30. Oxford University Press, Oxford.

BERTIN, R. I. 1982. Paternity and fruit production in trumpet creeper (Campsis radicans). Am. Nat., 119, 593-609.

BONNIN, I., PROSPERI, J. M. AND OLIVIERI, I. 1996. Genetic markers and quantitative genetic variation in Medicago truncatula (Leguminosae): a comparative analysis of population structure. Genetics, 143, 1795-1805.

BURTON, R. S. 1987. Differentiation and integration of the genome in populations of the marine copepod Tigriopus californicus. Evolution, 41, 504-513.

BURTON, R. S. 1990. Hybrid breakdown in developmental time in the copepod Tigriopus californicus. Evolution, 44, 1814-1822.

BYERS, D. L. AND WALleR, D. M. 2000. Do plant populations purge their genetic load? Ann. Rev. Ecol. Syst., 30, 479-513.

CARR, D. E. AND DUDASH, M. R. 1995. Inbreeding depression under a competitive regime in Mimulus guttatus: consequences for potential male and female function. Heredity, 75, 437-445.

CHARLESWORTH, D. AND CHARLESWORTH, B. 1987. Inbreeding depression and its evolutionary consequences. Ann. Rev. Ecol. Syst., 18, 237-268.

CONRAD, M., PARADIS, G. AND PIAZZA, C. 1989. Anchusa crispa Viv. Candollea, 44, 385.

CRAWLEY, M. J. 1993. GLIM for Ecologists. Blackwell Scientific Publications, Oxford.

DUDASH, M. R. 1990. Relative fitness of selfed and outcrossed progeny in a self-compatible, protandrous species, Sabatia angularis (Gentianaceae): a comparison in three environments. Evolution, 44, 1129-1139.

FISCHER, M. AND MATTHIES, D. 1997. Mating structure and inbreeding and outbreeding depression in the rare plant Gentianella germanica (Gentianaceae). Am. J. Bot., 84, 1685-1692.

HUSBAND, B. C. AND SCHEMSKE, D. W. 1996. Evolution of the magnitude and timing of inbreeding depression in plants. Evolution, 50, 54-70.

LEVIN, D. A. 1983. Plant parentage: an alternative view of the breeding structure of populations. In: King, C. E. and Dawson, P. S. (eds) Population Biology - Retrospect and Prospect, pp. 171-188. Columbia University Press, New York.

LYNCH, M. 1991. The genetic interpretation of inbreeding depression and outbreeding depression. Evolution, 45, 622-629.

MAIRE, R. 1904. Remarques sur la flore de la Corse. Rev. Bot. Syst. Géogr. Bot., 2, 21-27, 49-57, 65-73. 
PARADIS, G. AND PIAZZA, C. 1988. Description de la végétation de deux plages à Anchusa crispa du nord du Golfe de Valinco (Corse) plages de Cappicciolo et de Cala Piscona. Le Monde des Plantes, 433, 15-24.

PARADIS, G. AND PIAZZA, C. 1989. Contribution à l'étude de la végétation du cordon littoral et de l'arrière-cordon de Portigliolo (Golfe de Valinco, Corse). Bull. Soc. Bot. Centre-Ouest, NS, 20, 51-75.

PARKER, M. A. 1992. Outbreeding depression in a selfing annual. Evolution, 46, 837-841.

PIAZZA, C. AND PARADIS, G. 1988. Etude de la végétation de la plage de Campitello (Golfe de Valinco, Corse). Le Monde des Plantes, 431, 32-36.

PRICE, G. R. AND WASER, N. M. 1979. Pollen dispersal and optimal outcrossing in Delphinium nelsonii. Nature, 277, 294-297.

QUILICHINI, A. 1999. Biologie et écologie d'une espèce endémique corso-sarde rare et protégée: Anchusa crispa Viv. (Boraginaceae). Implications pour sa conservation. $\mathrm{PhD}$ Thesis, Université de Corse, 140 pp.

QUilichinI, A. AND DEBuSsCH, H. 2000. Seed dispersal and germination patterns in a rare Mediterranean island endemic (Anchusa crispa viv. Boraginaceae). Acta Oecologica, 21, 303-313.

RITLAND, K. AND GANDERS, F. R. 1987. Crossability of Mimulus guttatus in relation to components of gene fixation. Evolution, 41, 772-786.

SALIS-MARSCHLINS, U. 1834. Aufzählung der in Korsika und zunächst um Bastia von mir bemerkten Cotyledonartpflanzen. Flora (Regensburg), 17, 1-86.

SAS INSTITUTE INC. 1990. SAS/STAT User's Guide, version 6, vol. 2. Cary, NC.

SCHIERUP, M. H. AND CHRISTIANSEN, F. B. 1996. Inbreeding depression and outbreeding depression in plants. Heredity, 77, 461-468

SELVI, F. AND BIGAZZI, M. 1998. Anchusa L. and allied genera (Boraginaceae) in Italy. Plant Biosys., 132, 113-142.

SOBREVILLA, C. 1988. Effects of distance between pollen donor and pollen recipient on fitness components in Espeletia schultzii. Am. J. Bot., 75, 701-724.

SVENSSON, L. 1988. Inbreeding, crossing and variation in stamen number in Scleranthus annuus (Caryophyllaceae), a selfing annual. Evol. Trends Plants, 2, 31-37.
TANAKA, Y. 1997. Extinction of populations due to inbreeding depression with demographic disturbances. Res. Pop. Ecol., 39, 57-66.

TARAyre, M., SAumitou-laprade, P., Cuguen, J., COUVET, D. ET AL. 1997. The spatial genetic structure of cytoplasmic (cpDNA) and nuclear (allozyme) markers within and among populations of the gynodioecious Thymus vulgaris (Labiatae) in southern France. Am. J. Bot., 84, 16751684.

TEMPleton, A. R. 1986. Coadaptation and outbreeding depression. In: Soulé, M. (ed.) Conservation Biology: The Science of Scarcity and Diversity, pp. 105-116. Sinauer Associates, Sunderland, MA.

THIÉBAud, M. A. 1988. Contribution à la connaissance de l'Anchusa crispa Viv. en Corse. Candollea, 43, 390-396.

THOMPSON, J. D. 1999. Population differentiation in Mediterranean plants: insights into colonization history and the evolution and conservation of endemic species. Heredity, 82, 229-236.

TRAME, A. M., CODDington, A. J. AND PAige, K. N. 1995. Field and genetic studies testing optimal outcrossing in Agave schottii, a long-lived clonal plant. Oecologia, 104, 93-100.

VAlSECCHI, F. 1976. Il genere Anchusa in Sardegna. Webbia, 30, 43-68.

viviani, D. 1825. Appendix ad Florae Corsicae Prodromum. Genuae.

WASER, N. M. 1993. Population structure, optimal outbreeding and assortative mating in angiosperms. In: Thornhill, N. M. (ed.) The Natural History of Inbreeding and Outbreeding: Theoretical and Empirical Perspectives, pp. 173-199. University of Chicago Press, Chicago.

WASER, N. M. AND PRICE, M. V. 1989. Optimal outcrossing in Ipomopsis aggregata: seed set and offspring fitness. Evolution, 43, 1097-1109.

WASER, N. M. AND PRICE, M. v. 1991. Outcrossing distance effects in Delphinium nelsonii: pollen load, pollen tubes, and seed set. Ecology, 72, 171-179.

WASER, N. M. AND PRICE, M. V. 1994. Crossing-distance effects in Delphinium nelsonii: outbreeding and inbreeding depression in progeny fitness. Evolution, 48, 842-852.

WASER, N. M., PRICE, M. V. AND SHAW, R. G. 2000. Outbreeding depression varies among cohorts of Ipomopsis aggregata planted in nature. Evolution, 54, 485-491. 